\title{
The Performance of Citizen's and Organisational Authority
}

\author{
Mik-Meyer, Nanna; Haugaard, Mark
}

Document Version

Accepted author manuscript

Published in:

Journal of Classical Sociology

DOI:

10.1177/1468795X19860111

Publication date:

2020

License

Unspecified

Citation for published version (APA):

Mik-Meyer, N., \& Haugaard, M. (2020). The Performance of Citizen's and Organisational Authority. Journal of Classical Sociology, 20(4), 309-334. https://doi.org/10.1177/1468795X19860111

Link to publication in CBS Research Portal

\section{General rights}

Copyright and moral rights for the publications made accessible in the public portal are retained by the authors and/or other copyright owners and it is a condition of accessing publications that users recognise and abide by the legal requirements associated with these rights.

Take down policy

If you believe that this document breaches copyright please contact us (research.lib@cbs.dk) providing details, and we will remove access to the work immediately and investigate your claim. 


\title{
The Performance of Citizen's and Organisational Authority Nanna Mik-Meyer and Mark Haugaard
}

\author{
Journal article (Accepted manuscript*)
}

\section{Please cite this article as:}

Mik-Meyer, N., \& Haugaard, M. (2019). The Performance of Citizen's and Organisational Authority. Journal of Classical Sociology. https://doi.org/10.1177/1468795X19860111

\section{DOl: https://doi.org/10.1177/1468795K19860111}

Copyright (C) The Author(s) २०19. Reprinted by permission of SAGE Publications.

* This version of the article has been accepted for publication and undergone full peer review but has not been through the copyediting, typesetting, pagination and proofreading process, which may lead to differences between this version and the publisher's final version AKA Version of Record. 


\title{
The performance of citizen's and organisational authority
}

Nanna Mik-Meyer and Mark Haugaard

\begin{abstract}
This article explores the interaction of two forms of authority: organisational authority and citizen's authority. The concept of citizen's authority derives from Pettit and organisational authority has theoretical roots in Weber. Citizen's authority entails the right to be the author of your own life decisions, while organisational authority is the right of an actor to speak on behalf of an organisation. With inspiration from Goffman and Austin, we take a performative ethnographic approach to the analysis of 23 video-recorded consultations with homeless individuals (23), their family members (3), and service providers (43) in three Danish shelters. While those with organisational authority (staff) can prevail over those with only citizen's authority (clients), they typically refrain from doing so in an overt manner. We demonstrate that social actors are skilled at performing different kinds of authority simultaneously; they draw upon conflicting identities as clients, professionals, and citizens in a changing front-stage and back-stage environment. The homeless and staff deploy rules and procedures as well as emotion and laughter in their encounters with each other.
\end{abstract}

\section{Keywords}

Citizen's authority, Ethnography, (In)Felicitous actions, Organisational authority, Public encounters, Video data

\section{Introduction}


This article seeks to explore the performance of two forms of authority: 'organisational authority' and 'citizen's authority'. In the Weberian tradition, authority is characterised in terms of positions of command and obedience. In our research we will show that within public service organisations such as shelters, issuing commands to the public tends to be avoided. Part of the reason for this is that the organisational authority in shelters is limited by what we call 'citizen's authority'. The phenomenon of citizen's authority derives from Pettit $(2012,2014)$ and Haugaard (2018). While central in political theory, in Pettit's work, and theorized sociologically by Haugaard, few scholars have studied this form of authority empirically. In order to ascertain if citizens have authority over their lives, we have chosen to look for this phenomenon in the public service, where one would expect clients to be treated as citizens. However, we have selected the least powerful of all clients, the homeless, to establish if even they are able to display citizen's authority.

In this theorization, the concept of authority does not have the command/obedience connotation of Weber's account. Rather, inspired by Austin, it concerns the right of social actors to speak with authority, which means to be the author of your own actions and to be taken seriously. This change in emphasis mirrors the shift in emphasis in the power debates; from power as domination to power as agency (see for instance Allen, 1999; Giddens, 1984; Haugaard, 2012; Morriss, 2002; Pansardi, 2012).

Authority constitutes a form of agency that derives from status. In the case of citizen's authority, this agency derives from their status as citizens. It is an authority that in principle, in contemporary democracies, all social actors share. However, as feminists and minority rights campaigners argue, there can be huge discrepancy between the rights that exist in principle and the actual, sociologically visible, practice. To take an everyday example, persons with disabilities are, in principle, full citizens. Yet they often complain that persons without disabilities see them in terms of their impairments, and so deny them full agency (e.g., Shakespeare, 1996; Mik-Meyer, 
2016). When care-workers talk about the needs of disabled persons who are present as if they were absent (of the kind, "Does he take sugar? ...") this social action represents a disregard for the other as a social subject who, as a citizen, should have authority and hence be visible in the social interaction. If we had found that service providers largely talked about the homeless in the third person, and solved their problems by constantly resorting to organizational command authority, then the conclusion would be that citizen's authority was absent in these particular interactions. However, this is not our finding.

A central theme of the public service is slogans like 'client-centeredness', which point towards a recognition of citizen's authority. However, paying lip service to citizen's authority and actually allowing this form of authority to manifest itself as meaningful agency are two different things. It is quite possible that these homeless social actors are treated in principle as citizens while in practice their citizen's authority is constantly overridden by top-down command authority. As a sociological paper, we are focussed upon actual practice, to ascertain whether or not citizen's authority has an affect upon interaction, especially where there is a significant discrepancy of power resources between state service providers and members of the general public. Our theory is developed through careful analysis of video recordings of client-staff interactions, inspired by key ethnographic work (e.g., Bartesaghi, 2009; Boyd, 1998; Heritage and Raymond, 2005; Pilnick and Zayts, 2016; Stivers et al., 2018).

As will be explained in greater depth in the theory section, it is important to understand that authority in this article is about agency and enablement. We can observe citizen's authority when social workers, or other service providers, treat the homeless as social actors who are capable of choosing what is good for them, therefore as having the status authority to author their own lives. Often citizen's authority takes the form of service providers refraining from 
exercising the command authority (or deontic authority) that goes with their official organizational position. In these cases, the encounter almost looks like an encounter between friends.

The research question of this article is as follows: how is citizen's authority manifest in public service encounters in homeless shelters? In exploring this we are interested both in the manifestations of this authority in the actions of the homeless and equally in how the service providers, social workers, and representative of the municipality, try to negotiate this authority.

\section{Other studies and literature}

While, to our knowledge, there are no sociological studies that explicitly use the concept of 'citizen's authority', several studies examine how everyday authority is negotiated with social subjects who are both de facto citizens and comparatively less powerful than the service providers. This is well researched in medical settings, where an imbalance of authority exists between the medical expert and the patient. Authors often distinguish between what they term 'epistemic authority' and 'deontic authority' (command-like authority) (e.g., Heritage and Raymond, 2005; Mondada, 2013; Pilnick and Zayts, 2016; Stivers et al., 2018), when they examine how decisions are negotiated in real-life encounters. These studies are often inspired by a conversational analysis (CA) approach with a strong focus on the details in interactions. Heritage and Raymond's (2005) influential analysis show that participants exercise epistemic authority when they are able to make an independent stance in the sequence of the interaction (Heritage and Raymond, 2005: 16, 30). Similarly, participants have epistemic authority when they have the 'primary right' to particular elements of knowledge (Pilnick and Zayts, 2016: 349). Thus, access to knowledge about a field gives participants epistemic authority. When participants arrive at a 'terms of agreement' it displays who is agreeing with whom in specific situations. 
The goal in this line of research is to show that authority is continuously negotiated in social life. Often these studies - as Heritage and Raymond's (2005) study - centre upon the interacting participants' positioning in the field by deploying the techniques of CA. It is the participants' verbal expressions (including laughter, pauses, 'umm', etc.) that are key when investigating the negotiation of authority. They show how participants continuously deploy their 'epistemic rights' to regulate and sanction other speakers (Heritage and Raymond, 2005).

For instance, Peräkylä (1998: 317) finds that doctors' diagnostic evaluations are not simply structured as an unconditional, externally-granted authority relative to doctors' institutional status; rather, diagnostic evaluations of doctors are a relational phenomenon that is situationspecific. The strong focus on the situation-specific context, over organisational rule/position-based authority, is key to these CA-inspired analyses. Furthermore, in doctor-patients encounters, doctors exercise so-called deontic authority (command authority), that is 'the right to determine another's future actions' (Pilnick and Zayts, 2016: 349). Pilnick and Zayts (2016) argue in line with Stevanovic and Peräkylä (2012) that doctors usually have access to both types of authority. Doctors are positioned as the ones that know how the world 'is' (epistemic) and as the ones that know how it 'ought to be' (deontic) (Pilnick and Zayts, 2016: 349). Doctors or physicians are by definition in a position of greater authority because patients come to them for help and advice (Stivers et al., 2018). Even though one can argue - as Stivers and colleagues (2018) do - that doctors are in a powerful and authorial position, patients do not necessarily 'surrender [their] private judgments' (Starr, 1982: 15 in Stivers et al., 2018: 1335). Empirical studies show that doctors are reluctant to take on the deontic authority and tell the patients what they ought to do (Pilnick and Zayts, 2016). To echo Parsons' (1947: 58-60) findings, socially competent doctors seldom solely tell patients what to do. They also take on a more equal role of a person for whom it is legitimate to express everyday empathy with their patients. 
In Hutson's (2013) investigation of how authority plays out in the fitness industry, he finds that authority relates to the particular forms of capitals of this field. People with 'substantial institutional power' (attached to other fields) may find themselves without authority in the fitness industry if they have 'low levels of bodily capital' (Hutson, 2013: 64). In Boyd's (1998) investigation of medical peer reviews, he discovers two kinds of authority: collegial and bureaucratic. Modern organisations' widespread use of bureaucratic techniques such as protocols and standards make 'issues of bureaucratic regulation' as central as 'professional autonomy' in the medical field (Boyd, 1998: 201). He introduces the concept of 'bureaucratic authority', which is analogous to what we term organizational authority, as it is a kind of authority that is embedded in the organizational context - in his case: the bureaucracy. The organizational context is emphasised in yet another study that demonstrates how authority is rooted in 'the problem of context' (title of May's [2007] article ). May's (2007) point is that even though organisational encounters may appear as a 'dyadic' encounter between clients/patients and professionals, they always have a subtle implicit triadic element in the sense that the organisation itself and the field in which the encounter is part - 'context' - have an interactive presence. This third element is the resource that underpins what we term organizational authority.

Contexts are in Vinson's (2016) study a dominant discourse of 'patient empowerment' that bears a strong effect of the encounter between doctors and patients. In Bartesaghi's (2009: 15) research on therapeutic talk, perceptions of particular groups of clients must sometimes be altered, as they do not fit the dominant discourses - and, in effect, the subject positions of clients. She finds that in those instances where clients do not act as a stereotypical client - measured against this organisational specific context - then 'client talk is replaced by therapist talk'. Not all client perceptions of troubles are fit for therapy; therefore professionals 'reframe' the client's versions (Bartesaghi, 2009: 16). Using our theoretical frame, the interactions studied by Bartesaghi show 
how the citizen's right (in principle) to author your own life is in practice overridden by a form of paternalistic organisational command authority. However, to qualify this, the fact that the therapists go to considerable lengths to get clients to author their own stories, simultaneously demonstrates that citizen's authority is not entirely absent either. In terms of outcomes, in this case, the citizen's authority is over-ridden but in terms of the interaction it is still an active presence. Similarly, our analysis shows that when the citizen's authority of the homeless individual is at its weakest it still constitutes an absent presence.

Our study builds on this wide selection of studies that in one way or another emphasise the importance of including several levels of context - rules and procedures of organisations as well as the micro dynamics of human interaction - in analysis of client-staff encounters (Mik-Meyer, 2017). Following Goffman (1990), participants' (in our case: service providers) performance of organisational authority is characterised by following 'the rules of practice' (Manning, 2009). We demonstrate that social actors are skilled at performing different kinds of authority simultaneously; interweaving identities as clients, staff, and citizens in a changing front-stage and back-stage environment.

The two types of authority at play - organisational and citizen's - entail an asymmetry of power as service providers have both types of authority: they act on behalf of the organisation as well as on behalf of their position as citizen. Yet, to make the interaction flow smoothly, as our analysis will show, the participants - service providers and clients alike - try to accommodate two potential situations of conflict: 1) when the organisational authority of service providers cannot include the citizen authority of clients, and 2) when the two groups of participants - service providers and clients - have two perceptions of what it takes to hold legitimate citizen's authority today. 
Social life is conflictual; encounters are not always a smooth process. When clients fail to perform the authority of citizens (to act on their wishes and goals in life, etc.), in compliance with the goal of the organisation, an authority dilemma occurs. This authority dilemma is not easy to manage for service providers or clients, as it is the content of authority that is ambiguous: should it be related to clients' versions of citizenship, staff's version of citizenship, or the goal of the organisation (that may or may not be in alignment with the two versions). These situations of organisational dilemma and ambivalence often lead to back-stage actions, such as joking with each

other (see also Holmes, 2003; Kangasharju and Nikko, 2009; Mik-Meyer, 2007; Pouthier, 2017), and/or pronounced pauses in the interaction (Dupret, 2018). For this reason, we emphasise the micro components of scripted interaction, as these instances of laughter and pauses etc. point to moments of ambivalence caused by uncertain authority structures.

\section{Theory}

\section{Citizen's authority}

In sociology, the concept of authority has theoretical roots in Weber's work. He defined authority in terms of "the probability that a command with a given specific content will be obeyed by a given group of persons' (Weber, 1978: 53). This definition was linked to a view of modern organisational authority as inextricably tied to complex bureaucratic structures, with clear chains of command and legal rational modes of thinking (Benoit-Barné and Cooren, 2009: 8).

This command-oriented, virtually iron cage, view of bureaucracy has been challenged by many theorists who consider this characterisation symptomatic of a 'first modernity' (Beck, 1992) or 'simple modernity' (Giddens, 1990); now superseded by greater 'reflexivization,' and awareness of risk and contingency (Hoogenboom and Ossewaarde, 2005: 603). Furthermore, the Weberian view of authority is premised upon an inadequate theorisation of agency and structure. 
The agent is characterised as a representative of pre-existing, determinant, and organisational bureaucratic structure. Following Giddens' theorisation of structure as a process, as structuration (Giddens, 1984) and Bourdieu's emphasis upon the structuring of structure (Bourdieu, 2000), social structures (including authority) are reproduced by knowledgeable social actors. Social actors are reflexive beings who creatively perform the roles of authority. Authority is no longer simply the right to command based upon status position within an organization, as deontic authority. It is not simply power-over as domination (Haugaard, 2015). Rather, authority constitutes a form of agency that derives from status, which can either be organisational or derived from shared citizenship within a democratic polis. In the case of encounters in homeless shelters the service providers have organizational status and citizen's authority, while the homeless only have the authority derived from their status as citizens. Even excluding economic resources, there is an imbalance in authority, with the homeless having only one form of authority, while service providers have both. It is not an equal speech situation. Agency for the less powerful in this situation can simply be that the more powerful refrain from using their organizational command authority, appealing to more egalitarian and shared citizen's authority. In de facto structured contexts of imbalances of power, appeals to shared status and equality are signs of citizen's authority.

The concept of citizen's authority derives from Pettit's characterisation of the habitus of modern democracy as the universalisation of Roman republican ideas of citizenship (Pettit, 2012, 2014). In the Roman republic, citizens were the opposite of slaves. Slaves (even well-treated ones) defined their ends relative to the telos of their master, while citizens could define their own telos. In the early modern period, citizenship status becomes generalised. Everyone gains the freedom necessary to make life choices (Pettit, 2012: xix). Slavery is objectionable because the person is subject to the arbitrary domination of another (Pettit, 2012, 2014). In contrast, citizens have the authority to speak for themselves. In Haugaard (2018: 113), Primo Levi is used as an example of a 
modern social subject without citizen's authority. Levi was an Italian citizen, trained as a professional chemist, who found himself as slave labour in the laboratory of Auschwitz. Whilst he had the knowledge and competence to work in the laboratory, when he spoke to German employees who were not camp prisoners, they would not reply (Levi, 1991: 168). Levi had lost the authority to speak for himself. He could not author his own social agency. Forms of domination less overt than slavery or internment in Auschwitz, such as patriarchy, are normatively objectionable because those social subjects lack the authority to make their life choices. Pettit gives the example of the relationship between Thorvald and Nora in Ibsen's play A Doll's House (Pettit, 2012: xiii-xvii). Thorvald treats Nora well but because of the patriarchal social structures of society, there are significant decisions about her life that she cannot make without Thorvald's permission. In essence, she did not have the authority to author her own life. In modern society, the category of citizen is fundamental to society as a whole (Taylor-Gooby, 2010). All adult citizens should have the right to author their lives, which is citizen's authority (Haugaard, 2018). Furthermore, as argued by Abraham and Lewis (2002: 73), since the 1970's there has been a growth of a form of 'active citizenship', which is a consequence of increased reflexivity of late-capitalism. As a consequence of social actors exercising agency as consumers with lifestyle choices, they come to expect the right to agency in most spheres of their life. This is where in-principle political rights as citizens have slowly worked themselves into actual everyday practice. Within this framework, as in Jane Addams' account, citizenship is a multidimensional phenomenon that extends well beyond politics and includes everyday social interaction (Deegan, 2010: 232). As in Marshall's developmental model, contemporary citizenship is embedded in everyday social practices (Susen, 2010) and, as we are about to explore, this entails a kind of everyday citizen's authority. As in Marshall's model, rights start politically in principle but take many years to filter down to the micro-level of everyday social practice, which is the focus of this study. This is obviously seen with respect to patriarchy 
illustrated in Ibsen's $A$ Doll's House. Women were first recognized as equal citizens in principle, and given the vote and so on, but it has taken many years, and several generations for these abstract rights to work themselves out in everyday practice. In the USA women were enfranchised in 1920, which was an explicit recognition in principle of citizen's rights. However, the \#MeToo movement, which gathered momentum in 2017 , nearly one hundred years after enfranchisement, is a protest against the fact that in everyday social practice women do still not have full equality.

Citizen's authority today finds its in-principle expression in public service through client-centeredness, which means autonomy in life-choices (Hammell, 2013; Mik-Meyer and Silverman, 2019; Parsell and Parsell, 2012; Rogowski, 2010). However, in the case of homelessness, research shows that the homeless are perceived by professionals as categories of persons who have failed due to 'wrong choices' (Farrugia and Gerrard, 2016; Parsell, 2011; Parsell and Clarke, 2018; Parsell and Parsell, 2012). Professionals see it as their job to turn the troubles of clients into problems of social work (Gubrium and Järvinen, 2014). If these social subjects are not considered capable of making the right life choices it becomes tempting to make the (so-called) 'right choices' for them, treating them in a paternalistic manner, which means they are no longer authors of their own lives. This creates a dilemma for those with organizational authority, which is as follows: these homeless social actors are deemed not fully capable of making correct life choices, yet the public service should respect them as citizens, with full authority over their lives. Because of this dilemma, the case of homelessness constitutes an interesting counterfactual case for studying citizen's authority.

\section{Felicitous/infelicitous performance}

Organizational authority sometimes takes Weber's command form of authority, but with an emphasis upon power as agency, as the capacity for power to, we operate with a wider 
conceptualization of authority. Following the performative perspective, initiated by Austin (1975) and recently developed further by Searle (2007) in his influential essay, interactions in organisations are transactions where the organisation is made present through the authority of the speakers (Taylor, 2011). With respect to authority the base is a performance of status positions that is rendered either valid or invalid by those who respond. The communicative content of such interactions are not simply statements of fact but include a performative aspect that makes authority manifest (Austin, 1975; Searle, 2007; Taylor, 2011: 1281-1282). It is analogous to a purchaser offering paper currency for a product or service and the responding other either validating the paper as having the status of real currency, or simply rejecting it as a bit of paper. When a person performs an authority position correctly, her action is judged felicitous. Conversely, inappropriate performance is deemed infelicitous (Austin, 1975). The felicity/infelicity dichotomy is analogous to the epistemic true/false opposition in the sense that a felicitous performance is considered reasonable, while an infelicitous one is unreasonable. Yet, there is a qualitative difference, as displayed in Goffman's work (e.g., 1981, 1982, 1990) because there are significant affective and normative dimensions, which are neither true nor false in an absolute sense. Whether an action is considered to be felicitous or infelicitous depends on the situation - the rule of practice (Manning, 2009) - of which it is part.

Austin performs a thought experiment: imagine a large cruise ship is ready for a naming. The bottle of champagne hangs from the bow, in preparation for the Queen of England to name the ship the QE2. Instead Austin walks up to the ship and smashes the bottle against the bow of the ship, and states 'I name this ship the Mr. Stalin.' Has the ship been named? No, in fact we can agree:

1) that the ship was not thereby named; 
2) that it is an infernal shame

One could say that 'I went through a form of' naming the vessel but that my action was void or without effect, because I was not a proper person, had not the 'capacity,' to perform it... (Austin, 1975: 23-4).

While Austin's performance took the literally correct form, his action was infelicitous, therefore null and void. The performance of naming the ship was outside his specific scope of authority (Dahl, 1968), therefore infelicitous. The same act performed by the Queen makes authority present, and so felicitous/reasonable. The authority of the Queen of England constitutes a right to speak, as a felicitous act. Similarly, persons with organisational authority have the right to speak on behalf of the organisation, within the scope of authority set out by organisations.

To perform felicitously, social actors must show their tacit, practical knowledge (Polanyi, 1966) that renders them experts upon the norms of authority in various fields. In public encounters the norms of authority relate to an organisational logic of a particular field (Bourdieu and Wacquant, 1992; Emirbayer and Johnson, 2008) as well as an 'everyday life-logic' of what it takes to perform as a competent citizen. As explained by Bourdieu with regard to the concept of habitus, social actors always find themselves interpreting the world within a 'bounded rationality' that reflects their experience (Bourdieu and Wacquant, 1992: 126-127). Echoing Giddens (1984: 45), this is a form of 'practical knowledge' of how to 'go on' in everyday interaction. Using this habitus-based practical knowledge, social actors learn what types of social action will be felicitous or infelicitous. According to Giddens (1984: 26), at the level of tacit practical knowledge social actors are experts in their social life. When their knowledge proves inadequate, their reflections change the structuring of perception of the social practice of which they are part ${ }^{1}$.

\footnotetext{
${ }^{1}$ On habitus or practical knowledge there appears a slight difference between Giddens and Bourdieu. The former gives social agents greater reflexivity than the latter. Bourdieu refers to habitus using terms like 'unconscious' (2000: 18 and 78-79) or 'immanent law' (2000: 81), suggesting repression and determination, while Giddens argues that this tacit knowledge can become discursive (Giddens, 1984: 27) and, thus, open to reflexive agency. That said, in a passage
} 
Goffman's rich accounts of everyday life (1990) and institutional life (1974) show the performative nature of status authority. Social actors constantly have to present themselves to an audience in a dramaturgical manner, which presupposes complex tacit practical knowledge of how to 'go on' in a felicitous manner (Giddens 1984: xxiii). Goffman uses the distinction between frontstage and back-stage, with the former constituting the official version. While the back-stage can be a private space (such as dressing-rooms used by actors before they go on stage), Goffman largely uses the idea of the back-stage as an immensely social space. In his early work, Goffman describes how the indigenous Shetland Islanders used the front-stage for what outsiders were meant to know concerning social reality, while the back-stage knowledge was reserved for what the Islanders knew and recognized as what was really going on (Burns, 1992: 11). The front-stage can be characterized as the deliberate performance of the official version, while the back-stage becomes a space where another version of authority takes place. The back-stage is the ideal space for those with organizational authority to bracket it, and interact with the less powerful in a more egalitarian manner. While being invited back-stage appears egalitarian and friendly, it typically confers status authority upon the invitee. For outsiders to the Shetlands being invited back-stage by the locals resulted in an increase in status. In the interactions studied in this current article, back-stage is the part of interaction where hierarchical organizational authority is set aside in favour of more egalitarian and shared citizen's authority. For the homeless clients such a momentary invitation entails an increase in authority, which suggests that we are all equal citizens here. As those

\footnotetext{
where Bourdieu and Wacquant refer to actors as 'trapped' within their habitus (suggesting repression and determination), it is also acknowledged (between dashes) that these social actors are only trapped 'save to the extent [they become] aware of it' (Bourdieu and Wacquant, 1992: 126), which suggests convergence with Giddens' more reflexive account. Because of this slight difference we prefer to use the term practical knowledge, rather than habitus. However, although we are following Giddens, in this context we have dropped Giddens' use of the word 'consciousness' (as in 'practical consciousness knowledge') to emphasize that this is a sociological, not a psychological concept.
} 
occupying official positions are the more powerful ones, becoming equal is an increase in status authority for the less powerful - the homeless.

In everyday speech, authority has overtones of command (as in Weber), but in this sociological usage, authority is simply the right to speak and be taken seriously. In everyday life most social actors have the experience of wishing to offer advice to someone they know, but not all that well, and feeling that it is inappropriate because they do not have the level of friendship required. The status of being a friend means that you have the authority to give advice and that your advice is deemed felicitous. Similarly, in the client-staff interaction in shelters, the staff's appeal to the homeless person's citizen's authority has an egalitarian element of friendship and camaraderie. For the less powerful actor (the homeless), an invitation into that space of friendship constitutes an increase, not a decrease, in authority. Therefore, authority does not manifest itself as inherently hierarchical. It is about agency, the right to speak and be taken seriously and the right to author your actions. In contrast, abject powerless social actors, such as slaves, or Nora in Ibsen's play, do not have that kind of everyday authority. When social actors, without citizen's authority, speak up, their utterances are deemed infelicitous, whatever the content, thus a non-event as far as the more powerful others are concerned.

These switches between front- and back-stage are momentary events, which social actors signal to each other using devices such as laughter or a change in posture. In this regard the use of video recordings of real life encounters is crucial, when the goal is to reveal these moments when front- and back-stage switches of authority positionings take place. Body language often signals a move from organizational authority to citizen's authority.

\section{Methodology}


The following analysis is based on a dataset consisting of 23 video-recorded consultations with homeless men (19) and women (4), living in three shelters situated in different parts of Denmark. Eight of the 19 men are from Afghanistan, Ethiopia, Morocco, Somalia, Syria, and Greenland and the rest of the participants are ethnic Danes. We use video data to give informal expressions in the encounters, such as body language, equal attention as speech (Mik-Meyer et al., 2018). Video data provides a rich visual source of how organisational members display authority through body gestures and other more informal ways of interacting. Thus, video-recording is a useful dataacquisition tool as it enables the researcher to acquire informal and detailed knowledge about the object of the study (Heath and Luff, 2012; Heath et al., 2010).

Video-recordings offer insight into 'tacit' practical knowledge (Polanyi, 1966). It enables the researcher to spot things that are so taken for granted in an interaction that they are not necessarily verbalised in the encounter, or talked about in an interview. Scrutiny of body language reveals nuanced aspects of authority. When an organisational member draws herself to her full height, laughs in a particular manner, or fixes the other with a stare, these are signals of the invocation of the subtle norms of authority, which actors understand at the level of practical knowledge and respond to.

The video-recordings took place, by year-end, between 2017 and 2018. The homeless consultations involved a shelter resident, a shelter social worker, a municipality social worker, and in some instances client relatives, mentors, or other staff, including drug counsellors. Typically four persons participated in the consultations. On average, each consultation lasted fifty-seven minutes (longest 82 minutes and shortest 32 minutes). The camera was set up by Author A or a student, who greeted participants, then left the consultation (except in the first three consultations). The camera angle was a 'mid-shot' angle pointing at the table's actions as well as the actions of participants. Luff and Heath (2012) argue for the benefits of pointing a camera towards the action, for instance, 
the table-activity such as pouring coffee, taking notes, etc. as well as body activity such as bending forward, looking down, stretching etc., as these activities can be ways for participants to abstract from awkward situations. Afterwards, all participants were interviewed $(\mathrm{N}=77)$ on their own or, in a few cases, together. However, interview data is not part of our present analysis, which focuses solely upon the video recorded meetings.

The participants were recruited through the managers of the three participating shelters. Contacting managers ensured the shelters' acceptance in participation, which was followed by contact with shelter social workers and clients. Often arrangements with shelter social workers generated more consultations with other clients and municipality social workers. As an ethical standard, the contacted shelter social worker received written information about the research, including assurance of anonymity and the right of withdrawal at any point. The content of the written document was explained to participating clients and forwarded to social workers. Usually, more information about the project followed by phone or email. At the start of consultations, participants were re-requested permission to be video-recorded. All participants are anonymous all mentioned names and places are fictionalised. Rules for data storing/processing are fulfilled according to ethical standards.

After recording, the data (consultations and interviews) were transcribed in full, followed by a focused coding of key themes (Charmaz, 2006). This analysis was conducted by reviewing the videos and coded transcripts. Data have been analysed in two steps. First, one author viewed the videos several times to gain a thorough understanding. From this review it was clear that authority concerned more than following and applying organisational rules. Hereafter, the other author reviewed all the recorded consultations once, paying attention to the performance of authority. Based on all 23 video-recordings, both authors selected five paradigmatic cases displaying authority negotiations. The case selection was measured against sociological criteria, 
including, age, ethnicity, and gender. While the data presented stems from the five selected consultations, with two men from Syria and Morocco, two ethnically Danish men and an ethnically Danish woman - the presented analysis represents the entire data set.

\section{Findings}

Shifting back-stage equality to front-stage authority

Most consultations start by inviting the client to perform citizen's authority: as autonomous subjects who, as author of their life, can define his/her life problems, combined with a 'proper' solution to that problem (Gubrium and Järvinen, 2014). However, service providers take a risk with this opening because clients often present them with a problem/solution that is infelicitous relative to organisational logic.

This consultation opens with Caroline (Danish municipal social worker) greeting Salem (client, originally from Syria). Indicative of equal authority, the table is circular and Salem is offered 'whichever chair he likes', including the one Caroline has chosen. Salem sits down opposite, stretches in the chair, lifts hands above his head, and yawns exaggeratedly. This is clearly 'back-stage' action (Goffman, 1990). Laura enters (a Danish shelter social worker). Both social workers engage in protracted laughter and Caroline asks rhetorically, 'Does the day normally start a little later for you?' Their laughter suggests camaraderie, yet the speed suggests lack of ease, bordering on infelicity. Salem's opening is a presentation, or making present (what Benoit-Barné and Cooren term 'presentification') of egalitarian, back-stage, authority structure (Benoit-Barné and Cooren, 2009), which suggests a shared citizen's authority. Yet, there is unease because Salem takes the informality just a little too far. They have shared citizen's authority in principle, but maybe not in practice. 
Hierarchical authority is not usually overtly performed (Costas and Grey, 2018;

Stivers et al., 2018). Yet, the meeting must have an agenda. After a pause, Caroline laughs, as she stares at Salem, holding his attention with her eyes. She states that she and Salem have not met before, using self-introduction to slip into organisational authority: 'I am Caroline, and I work for the municipality...' While asserting organisational authority, this performance has a back-stage register: 'I sit with you, for you, and in that way I learn what your thoughts are in relation to what should happen with regard to accommodation...' Caroline moves up a gear, to formal register, by asserting that she must write an Action Plan, a document that represents organisational structure in all consultations. Caroline displays practical knowledge of the field through skilful performance of organisational authority intertwined with equal citizen's authority (Haugaard 2018; Clarke, 2005). Having set the agenda, she hands authority to the client by stating: 'I need to know what you think of this whole affair. That is first and foremost.'

Salem responds with nervous laughter and there is a lengthy (15 second) pause. He clearly does not know what to say, his eyes wander around the room, then to the floor; his tacit practical knowledge of the field is insufficient to know what response would be felicitous. Laura helps out. She draws herself up, to give herself physical presence, and prompts him to describe how he came to Denmark from Syria. The account of how Salem became a homeless client in Denmark is largely steered by Laura, engaging in social repair work (Collins, 2004; Goffman, 1982) to get him to stay relevant to the organisational agenda.

Salem states that he entered Denmark alone, without family, when he was sixteen. Laura stares at him, and pointedly asks, 'But how old were you really?' Laughing, she turns to Caroline and says in a low voice, 'We have heard that Salem is not really twenty-five.' Laura returns her gaze to Salem and he mutters: 'Eighteen'. Then Laura states, 'You were eighteen, now you are nearly thirty, right? That is the reality!' Rather limply, staring at his hands, Salem corrects 
her, 'I am 29, not thirty,' which still means he has lied but he 'saves face' by correcting her (Goffman, 1982). The background is that refugees cannot be sent home if entering Denmark as unaccompanied minors. Therefore, many claim to be minors, when they are not. There is low laughter from the social workers, while they force Salem to confess. They are officials and want the truth front-stage, yet laughter indicates back-stage nervousness at forcing him to say something he does not wish to say, thus moving away from the camaraderie atmosphere to using their organisational authority in a top-down manner. Going against the social convention of joining in on a joke, Salem does not laugh. Because the laughter is not reciprocated, the social workers' laughter strengthens their 'sense of community,' 'solidarity', and harmony (Pouthier, 2017: 755), which the client is not part of. This effect makes their organisational authority position more apparent.

The Action Plan agenda always includes the issue of substance abuse. Laura has to coax this problem from the client, with accompanying body language. She leans forward, fixes him with her eyes, to get him to confess that drugs are a problem. Salem avoids eye contact as he explains that hashish is good for him, as it helps him gain religious experiences. Salem starts a religious monologue. The social workers pull away, physically distancing themselves from him, whilst the tilt of their heads suggests puzzlement. The social workers need to stop this organisationally irrelevant monologue. Salem's profession of faith is also infelicitous relative to the secular norms of Danish society, where religion belongs to the private sphere. The Danish variant of citizen's authority includes the tacit assumption that if you are religious then keep it a private matter. Salem is apparently not aware of the particular status of religiousness in Danish society. Laura, who has been looking at Salem, suddenly switches her gaze to Caroline. Salem pauses, and Caroline grasps the cue to switch the conversation back to an organisational topic. She frowns, leans forward, and uses what he has just said to get him to change the subject. The exchange is as follows: 
Salem: I can explain... the last prophet, the last human. ... He belongs to all people... He is good to you, if you do good things. Then you get salvation from the twelfth prophet, right? ... God arrives with you, and you walk to Paradise together, and the door opens. But if you're a bad person, when you die, then you're sent to hell.

Caroline: When you have all these thoughts, do you then have room for other thoughts? Like, thoughts about how you'd like to live, and where you'd like to work and those kinds of things? I can tell that it takes up a lot of space in your head.

Salem: Yes, I like to work... I love to work...

Salem's active participation in the meeting is felicitous (he is an active client sharing his thoughts), but the content of what he is saying is infelicitous. Caroline redirects him again to the issue of his accommodation and future work life, as these topics are within the specific scope of situational relevant organisational authority. What follows is a lengthy conversation, where the client requires some guidance, while he also displays practical knowledge of organisationally relevant information concerning his housing needs and drug abuse. He does not revert to private themes (as defined by organisational and Danish practical knowledge) concerning religious faith.

The opening of the consultation demonstrates a tension between giving clients authority as citizens who can author their own lives (Haugaard, 2018; Clarke et al., 2007), while requiring an organisationally relevant outcome (Mik-Meyer, 2017; Bartesaghi, 2009). When Salem goes off topic, this suggests the need for organizational authority in order to make a strong move (Latimer, 2004). Both service providers use their skilled practical knowledge of interaction to 
weave the performance of citizen's and organisational positions of authority together. The strongmove subject change is probably the moment when the dilemmas posed by the performance of these two forms of authority are most visible, yet even here the social actors try to graft the one into the other. The line: 'When you have all these thoughts, do you then have room for other thoughts?' is an attempt to respect what he is saying, with citizen's authority, yet redirect him in an organisationally relevant direction. Salem picks up on the cue, demonstrating some practical knowledge of the context, as he willingly redirects to topics felicitous to organisational authority. While these actors share significant practical knowledge, Salem's exaggerated informality at the start, combined with his lack of awareness that the Danish view of citizen's authority is part of a strongly secular tradition, shows there is a significant mismatch of practical knowledge rooted in cultural difference. This discrepancy creates problems for all of the social actors involved. Yet, they show remarkable reflexive ability, which enables them to overcome these tensions. Emotion and laughter are a lubricant that eases the interaction and makes it flow, despite differences in practical knowledge.

\section{Shifting organisational authority to citizen's authority}

Sofia is in her forties and has lived at the shelter for 1.5 years. She is dressed in coordinated shades of navy and black, her hair neatly groomed, and wears pearl earrings. Adam, a male social worker from the shelter, is dressed smart-casual. The service provider from the municipality, Lisa, wears a flowery shirt, green jeans, and her hair falls over her face. Judging solely by appearance, it is easy to mistake who has organisational authority. However, when Lisa takes the floor, she asserts her authority by refusing a short interview, pertaining to this study: 'I have not reserved time for that.' In contrast, Sofia accepts the interview with 'Yes, I am here anyway.' It is clear who has the 
organisational authority and is in charge: Lisa is the kind of person who has a busy schedule, whereas Sofia has all the time in the world.

The formal part of the meeting opens with a curious incident where Adam's organizational authority is undermined by lack of preparation. Ironically, this revelation begins with Lisa complimenting Adam upon his report. She states that 'it is a very fine report you have written, Adam...' which she follows with 'it is very comprehensive and detailed, and that is useful. You get a good sense of Sofia [gesturing towards Sofia with her hands] so that Sofia does not have to explain everything to me again.' Embarrassed, Adam admits that the report is nearly one year old. Lisa gestures surprise and says 'A year old. Is it really?' and repeats 'Is it a year old - this one that you have authored?' The inadequacy of Adam's report undermines his organisational authority position as an expert upon the client's position. However, most of the time Sofia effectively represents herself to Lisa, which is consistent with the citizen's authority goal of the client authoring her own life. We learn that Sofia wants a pension and that this consultation is a kind of 'oral application'. This objective structures Sofia's actions. To qualify for a pension, she must emphasise her problems and dependency to the social workers. While this makes her a cooperative client, who does not stray off-topic, the flipside is that being dependent works against her citizen's authority as a person that can come up with the solution to her troubles herself. The two service providers have to do repair work (Goffman, 1982) to emphasise her status as citizen.

An aspect of her dependency is the shelter's administration of Sofia's use of methadone and email. This supervision seriously compromises her private sphere as a citizen who authors her own life. With respect to the methadone, Adam states 'It's not because Sofia isn't responsible and could administer it herself, but in the shelter we have rules that apply to medicines that can be sold [on the black market] and that create dependency...' In fact, there is nothing unusual about controlling methadone; Adam is making the point that he respects Sofia's citizen's 
authority - 'she is responsible and could [but doesn't] administer it herself.' With respect to monitoring her emails, he says apologetically 'We don't control you, we need to... [and then motions with his hands to suggest 'help you along']' and Lisa chips in: 'We are making you autonomous,... well more so, actually...' The supervision of emails suggests dependence, while autonomy signals citizen's authority. With regard to both issues, her citizen's authority is an absent presence (Costas and Grey, 2018). It is literally outcome absent, yet referred to.

\section{Toning up and toning down authority}

The negotiation of authority takes place in a continuum. In most consultations, service providers are reluctant to take on the role of organisational authority. Yet, rule-abiding decisions have to be made. The consultation with Martin is unusual as it begins with the display of organisational authority upfront. Martin is ethnically Danish, in his early forties, dressed in cool, casual clothes, with sunglasses in his hair. The social workers are ethnically Danish - early middle-aged, one older.

Unusually, this consultation opens with a hierarchical use of space. The municipality service provider, Helen, sits alone at one side of a large rectangular desk on a raised office chair, which is a foot higher than the chairs of the other participants. Opposite, on the other side of the desk, are Martin, his mentor, and a local job centre service provider. Helen's computer partly blocks her view of Martin. There is not really room for the three of them to sit at one side of the desk, so Martin sits squeezed up against the wall. This physical arrangement suggests a manifest presence of organisational authority, while citizen's authority appears absent.

Like the three professionals, Martin has brought along a folder with documents, including his personal journal and printouts of activities at the jobcentre. His folder symbolises organisational authority, except that he has insufficient room to manage it, constantly dropping papers. Commensurate with the overt physical representation of hierarchical authority, Helen greets 
everyone in a brusque manner: 'On a practical level: do we actually have an agenda?' The mentor suggests a few issues, which Helen overrides by asserting that she does not see any reason to meet.

This explicit demonstration of organisational command authority makes Martin nervous and he fidgets with his papers. Then, he leans forward, coming out of his corner, and performs citizen's authority by stating that the reason for the meeting is that he is afraid that Action Plan decisions will be made without his consent. This explanation resonates overtly with clientcenteredness, as in the case of Salem who also took the floor (Hammell, 2013; Rogowski, 2010). In response, Helen relaxes her top-down authority: 'Of course' his input is required, 'it makes good sense', including encouraging 'umm' and 'yes's'. In short, she validates his bid for citizen's authority.

Consistent with citizen's authority, Martin is expected to open with a statement concerning his view of his 'troubles' (Gubrium and Järvinen, 2014). Martin mentions trouble committing to assignments, which stresses him. Then, with slight laughter, he slips in a practical challenge (washing clothes), with a solution: he has come across a washing machine for only $£ 50$. All agree that this is cheap. Helen states it would be nice for Martin to buy this washing machine, as 'the local laundromat is so expensive'. However, she does not suggest that the municipality should pay for it. No-one asks directly but the request is obvious, it appears reasonable, yet everyone understands who has organisational authority - the washing machine is not part of Helen's agenda.

Accepting this, Martin slowly builds up a personal narrative of a hardworking, good ex-husband and trustworthy kind of guy. He states 'It is not that I want to polish my glory,' which is exactly what he is doing. Martin's presentation of himself as responsible (Clarke et al., 2007), capable of performing citizen's authority, is felicitous. Helen softens her performance of organisational authority, adopting a friendly tone and disposition of equal 'footing' (Goffman, 1981). In her characterisation of Martin's problem we learn the reason for the initial use of official, 
overtly hierarchical, authority. In a previous meeting, Martin was difficult to cooperate with. As an unemployed citizen he had 'unrealistic' plans that were infelicitous relative to the policy goal of employment. His previous job plans included travelling to the US to set up a business. In contrast, this time he engages with the possibilities offered by the local job centre.

In the Action Plan, the problem of drugs must be addressed. However, compared to the opening, Helen is flexible. Martin's intake of hashish qualifies as 'a problem' but not 'such a big problem' that it demands immediate remedial action. Towards the end of the meeting the atmosphere becomes one of distinct camaraderie, with long slow laughter, showing reduced tension among the participants (Kangasharju and Nikko, 2009; Pouthier, 2017). Finally, Martin introduces the subject of his housing contract: he needs money for the first month's rent. In this transformed, friendly atmosphere, this problem is better received than his implicit request for a washing machine. Helen states twice: 'We will figure that out'. This is an informal register, implying they will pay for the first month's rent, without formal appeal to the bureaucratic procedures, is suggestive of equal citizens in co-performance. Here is a classic instance of where a back-stage friendly tone signals a move toward egalitarian relations which, from the perspective of the less powerful, constitutes an increase, rather than a decrease, in authority. It is like the Shetland islanders conferring status upon a visitor by dropping front-stage pretences and inviting the other back-stage, from the living room into the kitchen, to see how things really are. With Martin's financial problem resolved, the meeting ends. Martin's laughter and relaxed countenance suggests relief - they are all friends now.

When confronted with top-down organisational authority, Martin asserts his right to perform citizen's authority, as author of his life. He performs in a manner that respects organisational authority, which makes his agency felicitous. He is careful not to be overtly confrontational, and presents his life-plan in a manner commensurable with organisational logic he is reasonable. In response, Helen relaxes her performance of organisational authority, tending 
toward co-performance of equal citizen's authority. This constitutes an increase in authority for Martin, which gives him agency to solve his practical problems. However, this agency is circumscribed by adhering to practical knowledge of what is reasonable according to organizational logic and authority.

\section{Handing over and taking back authority}

Ali is a male in his thirties of Moroccan background. The two social workers are Danish women of a similar age. The social workers begin with friendly, back-stage questions (Goffman, 1990): does he want to take off his jacket and how he is feeling? Ali returns the back-stage approach. He feels awful because his girlfriend is pregnant and about to have an abortion.This is a deeply personal issue that belongs back-stage, among close friends in a private setting, not in the back-stage of a shelter consultation. The social workers look away, suggesting infelicity, but Ali does not pick up on the cue and continues to talk about the upcoming abortion. He explains the crux of the problem: the girlfriend is not supposed to be with him; she lives with her parents who do not know of his existence, which suggests an abortion as a solution. However, he does not approve of abortion. The social workers chip in, accompanied by nervous laughter (Kangasharju and Nikko, 2009; MikMeyer, 2007), with an appraisal of the story that simultaneously suggests felicity and infelicity as follows: he is right to be so honest with them but wrong to keep talking about it, as this is not a problem that can be solved through their organisational authority positions. From the perspective of organisational authority, it is only relevant as 'Yes, we get it. You are under stress right now.' As with all problems that are infelicitous to the organisational agenda, they have to be stopped. Andrea, municipality social worker, directs him toward the organisationally relevant Action Plan. Speaking 
in a low voice, eyeing him, she acknowledges his predicament but redirects: 'So that's [the abortion] what bothers you right now?' Ali nods. Then Andrea draws herself up and continues, 'So, perhaps I should tell you why I'm here. That's because I have to make a so-called Action Plan.' She makes the organisational agenda explicit, then emphasises that he is expected to co-author these outcomes, acknowledging citizen's authority: 'My job is to set some goals with you.' She gesticulates to hold Ali's attention, 'We need to decide what we are going to work with while you live here.'

Clearly the abortion is not relevant to the Action Plan; Ali accepts the new agenda and the topic of abortion is never mentioned again. From now on, Ali talks about topics relevant to Andrea and Josephine's (second social worker) organisational authority. He talks about his housing situation, his future, his brother as a role model, and so on. At one point Josephine and Andrea articulate the double performance of authority in these consultations whilst laughing overtly:

Josephine: You are good at explaining your situation to us. [Josephine speaks softly. Ali is restless, and looks from side to side]

Andrea: Yes. You are making it very easy for us. [Andrea speaks louder and Josephine laughs. Ali also laughs, but briefly, with a look of discomfort.]

It is unusual that service providers state the organisational dilemma, normally kept in a professional back-stage environment, unarticulated. Yet, as the shared laughter suggests, service providers know about this back-stage secret. Ideally, client-centeredness means that clients should be respected as authors of their own lives. However, most clients go off-topic, when given the authority of their citizen position. Therefore, the social workers have to perform their organisational authority to 
make them stick to the agenda. In this case, that was only necessary initially. As in the case of Salem, there is not total synchrony of how to interpret the friendly, opening atmosphere, but they smoothly help Ali to understand clearly the limits of how personal and how private the problems he shares with them should be. Abortion crossed that line. In the end, Ali is so 'reasonable' (relative to practical knowledge of the organizational field) that he is invited back-stage to learn about the secrets of service-providers.

\section{Giving authority to a client}

Brian is an ethnically Danish homeless man in his early sixties. He enters the consultation room slowly with the help of a walker, which becomes entangled with the door, drawing attention to his disability. The participating service providers are Jonas (municipality social worker), Sara (student from shelter), and Adam (shelter social worker). Brian's sister and niece are also present. While Brian sits down, the rest shake hands whilst standing. Brian puts his hands on the table, scratches his beard, moves the walker closer, sits back, and looks down at his hands. He appears apart from the rest, in his own private back-stage space, which is a quality that characterises the meeting, except for the end. Finally, everyone sits down. Jonas explains the Action Plan.

Brian's main problem is a delicate one. He was evicted from his apartment because it was filthy, with a ruined floor. Usually it is the client who states the problem, here the relatives act on his behalf. Jonas requests details, 'The floor that was ruined. How did that happen?' The niece explains:

Niece: Um, yes, I don't know [looks at Brian for eye contact but he does not respond, looking humble]. I think sometimes... [pause, shifts attention to Jonas] it came from him sitting on the couch and sometimes when Brian got a fit he might have urinated as 
well. Maybe some wine was spilled as well. It just stayed there and deteriorated... [Brian covers his mouth with his middle finger - embarrassed]

She continues in a halting manner, visibly uncomfortable with talking about her uncle in his presence this way (Shakespeare, 1996) yet she clearly wants the problem on the agenda confronted. To spare her uncle's dignity, she includes qualifiers, such as 'Well, sometimes Brian did wipe it up when something was spilled.' After a while, Jonas responds by using both his hands as calming gestures to stop her, and states that the problem is formally confronted: 'But everything regarding that has been taken care of now...' The niece smiles at Jonas, looking relieved. Her mother (Brian's sister) looks at Brian, who appears mortified. Jonas looks back and forth between the niece and Brian. It appears that the social worker is attempting to elicit engagement from Brian, who remains silent. His body language suggests that this silence is not resistance, anger, or irritation. Brian sits hunched up, making himself small, looking at the ground, suggesting that he wishes that the ground would swallow him up.

His niece, sister, Adam, and Jonas talk about Brian's stay at the shelter. His sister who, all along, has been less forceful than her daughter, does social repair work (Goffman, 1982). She tries to save Brian's dignity with assertions such as 'But it's clear that he's gotten so much better by getting regular food and medicine.' Everyone looks at Brian. Finally, all eyes resting on him, Brian responds with a faintly uttered monosyllabic: 'Yes.' The social worker, Adam, tries more repair work to get Brian to define which problems Brian thinks are most important. Adam moves focus from his personal situation to the inadequacy of the services and accommodation: 'But there are so many things that could be better, to be frank.' Adam laughs nervously and Brian responds with a faint smile. They are slowly turning the 'public disharmony' into solidarity (Pouthier, 2017). Adam continues: 'This isn’t exactly the best place for you [addressing Brian].' In 
response, for the first time, Brian utters a full sentence: 'No, I have to say. This isn't the place for me [hands folded, he clears his throat and looks at Jonas].'

In this case the client does not use silence to resist organisational authority. The performative role of his silence (Dupret, 2018) expresses embarrassment-cum-humility, leading to the absence of everyday citizen's authority. Jonas and Adam try to get Brian to talk, consistent with citizen's authority, but they fail to get more than monosyllabic responses, except at the very end. Brian talks for only 5 minutes out of the 70 minutes the meeting lasts. It is Brian's sister, and especially his niece, who assume the authority to name his problem. The details constitute a glimpse into a reality of troublesome squalor, which families typically keep back-stage. Brian requires resources from the municipality to enable him to regain control of his life. His sister and, especially, his niece take upon themselves the uneasy task of revealing back-stage problems to gain the necessary resources. The social workers try desperately to include Brian in the conversation - to give him citizen's authority to author his problems - but Brian performs by staying silent (Dupret, 2018). In this case it is not the authorities that make him abject, stripping citizen's authority from him, but his well-intentioned family members. In the end, it is largely left to the service providers to restore Brian's dignity by moving the blame for current problems away from the client and toward social services. This is a creative performance, which finally, in a small way, allows Brian authority to speak for himself - to perform citizen's authority.

\section{Authority, laughter and silence}

Laughter and silence are part of all of the 23 consultations. Social workers laugh more than clients, but clients laugh as well. Both parties use silence performatively (Dupret, 2018) to refrain from answering questions directed at them, either because they do not have the practical knowledge of how to go on or as acts of passive resistance. When clients are silent in response to requests or 
statements, they reject the organisational authority of social workers. In these cases, social workers usually laugh in order to tone down their organisational authority, just rejected by the clients. Laughter signals ambiguous and tense situations created by the interactive dilemmas (Mik-Meyer, 2007; Kangasharju and Nikko, 2009; Pouthier, 2017). Social workers' performance of organisational authority may not align with clients' performance of authority as a citizen, which includes the right to author their own story. Joking and the accompanying laughter signal underlying 'public disharmony' (Pouthier, 2017), or an imbalance of the two kinds of authority. In the consultations, the Action Plan creates demands of the clients and results in dilemmas for the service providers. This includes obligations that both parties know the clients cannot manage. Yet, while performing organisational authority, service providers must try to align the client's performance of citizen's authority with organisational obligations. For instance, in order to qualify for rent assistance, clients are obliged to show intent to save money. Most clients either argue that saving is impossible, or respond with passive-resistance silence. Social workers have the invidious task of acknowledging in a back-stage camaraderie manner, that saving is unrealistic. Organizational authority entails convincing the client that they must save money to fulfil the official criteria for eligibility for rent-assistance. Service providers explain that the rules state that the client must show 'intent' to save, which creates a loophole: the client can open a savings account and put a tiny amount in. That qualifies as intent. Coaching clients to bend the rules makes them back-stage co-conspirators, thus of equal authority. This subversion is invariably accompanied by nervous laughter (Grugulis, 2002; Mik-Meyer, 2007; Pouthier, 2017). Laughter and other face-saving practices aim at ameliorating organisational dilemmas (Goffman, 1982). The social workers must encourage the clients to perform as if they were citizens with authority concerning their economic situation while asserting organisational authority, which demands saving. 
Often clients address important questions in a half-laughing, joking atmosphere, acknowledging that the controversial suggestion may render their performance infelicitous. In these situations it becomes part of the repertoire of the performance of organisational authority to use silence to demonstrate that this is an infelicitous demand. When this happens, the interaction resumes as if the suggestion had never been made. Alternatively, a half-joking suggestion can be accepted as felicitous, validating the suggestion, which gives the homeless person the authority of a citizen.

In instances where the homeless person comes from a different cultural background than the social workers, where practical knowledge may not be in perfect synchrony, it is not entirely clear which actions are deemed infelicitous and felicitous. Here nervous laughter indicates infelicity and a lack of reciprocity of laughter (from either party) indicates division and latent conflict over meaning.

\section{Discussion}

Based upon a performative interpretation, influenced by Austin and Goffman, we have theorised authority as a right to speak, to be heard, and taken seriously, within a specific scope of authority. Those who perform organisational authority - service providers at shelters and municipalities have authority to speak upon organisationally relevant issues. The homeless person in the role of a client is expected to engage in a performance that demonstrates citizen's authority. The latter authority comes from two inter-related discourses: from the everyday democratic traditions of Danish society; and from the ethos of public service provision, which emphasises clientcenteredness, as the client's right to choose for themselves (Clarke et al., 2007; Parsell and Parsell, 2012). 
The client's problems are deemed 'solved,' when s/he is capable of living in a manner commensurate with the kind of autonomy that characterises the performance of citizenship (TaylorGooby, 2010). Yet, of course, they are homeless clients, so unlike most citizens, this includes comprehensive supports (Ravenhill, 2008). The unspoken performance dilemma is that these clients are living in homeless shelters and, as empirical studies have shown, are perceived by professionals as persons who have failed, due to 'wrong choices' (Farrugia and Gerrard, 2016; Parsell, 2011; Parsell and Clarke, 2018; Parsell and Parsell, 2012).

The source of these citizens' shortcomings has to be named as their problem (Gubrium and Järvinen, 2014). In terms of sheer organisational efficiency it would be easier for the service providers, with organisational authority, to name the problem, and prescribe the solutions, in a top-down manner. However, this would entail making the client comparatively abject, taking their citizen's authority away from them. It would mean asserting organizational command authority with the effect of undermining citizen's authority. To avoid this, the service providers often go to considerable lengths to get the clients to articulate/author their own problem, as citizens.

In most consultations, the interaction opens by allowing the clients autonomy to name their problem, thus to perform citizen's authority. That is with the exception of consultations where there is a previous history of the client articulating her/his problem incorrectly (according to organizational logic). In these cases, organisational authority is performed straight away. In consultations where the client is invited to set the agenda, the meeting begins with a lot of interactive phatic communion, laughter, and general politeness, in order to frame everyone as on an equal 'footing' (Goffman, 1981). The client is given authority but, quite frequently, goes off topic, relative to the organisational agenda. Once this happens, organisational authority is performed, usually in an apologetic manner, which implicitly acknowledges citizen's authority. The service providers do not take observable pleasure in the organisational authority structures. Rather, they 
appeal to the structural constraints of the Action Plan. Simultaneously, they try to graft the change of direction onto what the client has already said, that is as an absent presence of citizen's authority.

In consultations where the clients know, as practical knowledge, how the system works, they present their troubles in a felicitous manner, thus assertion of organisational authority is unnecessary. In others, the clients learn to become topic-relevant along the way, hence require no further steering from those in organisational authority. Finally, some clients have to be directed throughout the consultation. The less the service providers have to direct clients to be organizationally relevant, the more the clients are doing the work of the service providers for them.

The performance of authority is carried out on a scale. At one end, the performance of citizens authoring their own problems/solutions is most visible, while at the other end the social workers are visibly performing organisational authority. However, at both ends of the scale the other form of authority is still an 'absent presence' (Costas and Grey, 2018; Ward and Winstanley, 2003). When the clients speaks felicitously for themselves, they appear autonomous, but what enables them to have this agency-cum-authority is that they have practical knowledge of what is felicitous or infelicitous relative to the performance of organisational authority. At the other end of the scale, when the service providers reject what the client says as infelicitous, organisationally irrelevant, and then inform them 'what really is their problem/solution,' the performance of organisational authority trumps the client's performance. However, typically, they appear conscious of taking citizen authority away from the client. Congruently, they will do social repair work (Goffman, 1982) by, at the very least, acknowledging that they have not forgotten that the client should have citizen's authority, even if this is not the current reality.

An obvious question that can be raised by our characterisation of citizen's authority is to what extent this kind of authority makes a difference in the client's social life? Citizen's authority is a meaningful position of authority in two senses. Firstly, when the clients are acting in an 
organisationally relevant way, they gain the cooperation of the service providers, thus a greater capacity to resolve their problems, which concern real issues - sleeping on the streets, drug abuse, disability, unemployment, and so on. In these cases their citizen's authority provides them with problem-solving agency. Secondly, if we consider power as the capacity to have an effect upon the actions of others (Haugaard, 1997), even when not overtly present, then the idealised image of the citizens taking control of their own lives, speaking for themselves, does have tangible effect upon the actions of the service providers.

Organisational decisions are ritualised interactions (Collins, 2004; Goffman, 1982, 1990). Even when the performance of social workers suggests top-down authority, they still go to considerable lengths to try to give the clients voice. When that fails, they ritually acknowledge the client's citizen's authority, thus it is still an observable 'absent presence' (Costas and Grey, 2018; Ward and Winstanley, 2003). Of course, we acknowledge that when the relative power of the performance of citizen's authority is compared to organisational authority, this is not an egalitarian situation. When a conflict arises between the performance of citizen's authority and organisational authority, the outcome is usually that organisational authority prevails over citizen's authority.

\section{Concluding comments}

Overall, this article contributes to our sociological understanding of the content of authority by showing that citizen's authority is real in its effects; that authority is scalar and negotiated in a shifting front-stage and back-stage environment. In the Weberian tradition, authority appears as a command/obedience relationship (Weber, 1978: 58), where social actors either have the authority to command, or they do not. Building upon Austin (1975), Benoit-Barné and Cooren (2009), Taylor (2011), Goffman $(1981,1982,1990)$ and Goffman-inspired work, we show that authority is usually less than full command. Rather it entails a performance that includes the right to speak and be taken 
seriously. The performance of a particular kind of authority is often nested within other forms of authority. The less powerful actors in these interactions perform citizen's authority (Haugaard, 2018), while the more powerful perform both organisational and citizen's authority.

Citizen's authority is less powerful than organisational authority. Yet, it still has a significant effect upon the interaction. While those performing organisational authority can prevail over those performing only citizen's authority, thus can exercise command/compel obedience over others, they typically refrain from doing so in an overt manner. When they command, they typically acknowledge citizen's authority in some way. However, there are instances where citizen's authority is reduced to an absent presence. In such cases, the outcome is primarily driven by organizational authority, while citizen's authority is visibly present but without significant outcome effect.

The performance of authority is nuanced, nested, and has an affective element. Those performing organisational authority share citizen's authority with clients. They perform to create a friendly atmosphere, weaving in and out of front-stage and back-stage interaction. In the Weberian tradition there is a tendency to think of modern organisational authority as cold, legalistic, almost like an iron cage. However, using the performative tradition of Austin, Goffman and a number of CA-inspired studies, we demonstrate that through their dance-like weaving in and out of different forms of authority, using front-stage and back-stage, the performance of authority has a lived quality, as a phenomenon that is reproduced through emotion, laughter, and embarrassed, or sometimes hostile, silences.

\section{References}

Abraham, J., \& Lewis, G. (2002). Citizenship, medical expertise and the capitalist regulatory state in Europe. Sociology, 36(1), 67-88. 
Allen, A. (1999). The Power of Feminist Theory: Domination, resistance, solidarity. Boulder Colorado: Westview Press.

Austin, J. L. (1975). How to Do Things with Words. Oxford: Clarendon Press.

Bartesaghi, M. (2009). How the therapist does authority: Six strategies for substituting client accounts in the session. Communication and Medicine, 6(1), 15-25.

Beck, U. (1992). Risk Society: Towards a New Modernity. London: Sage Publications.

Benoit-Barné, C., \& Cooren, F. (2009). The accomplishment of authority through presentification. Management Communication Quarterly, 23(1), 5-31.

Bourdieu, P. (2000). Outline of a Theory of Practice. Cambridge: Cambridge University Press.

Bourdieu, P., \& Wacquant, L. (1992). An Invitation to Reflexive Sociology. Cambridge: Polity Press.

Boyd, E. A. (1998). Bureaucratic authority in the "company of equals": The interactional management of medical peer review. American Sociological Review, 63(2), 200-224.

Burns, T. (1992). Erving Goffman. London: Routledge.

Charmaz, K. (2006). Constructing Grounded Theory: A Practical Guide through Qualitative Analysis. London: Sage.

Clarke, J. (2005). New Labour's citizens: Activated, empowered, responsibilized, abandoned? Critical Social Policy, 25(4), 447-463.

Clarke, J., Newman, J., Smith, N., Vidler, E., \& Westmarland, L. (2007). Creating CitizenConsumers. Changing Publics and Changing Public Services. London: Sage.

Collins, R. (2004). Interaction ritual chains. Princeton, N.J.: Princeton University Press.

Costas, J., \& Grey, C. (2018). Violence and organization studies. Organization Studies, 1-14. https://doi.org/10.1177\%2F0170840618782282

Dahl, R. A. (1968). Power. In D. L. Shills (Ed.), International Encylopedia of the Social Sciences, 
vol. 12 (pp. 405-415). New York: Macmillan.

Deegan, M. J. (2010). Jane Addams on citizenship in a democracy. Journal of Classical Sociology, 10(3), 217-238.

Dupret, K. (2018). Performative silences: Potentiality of organizational change. Organization Studies, 10(5),681-703

Emirbayer, M., \& Johnson, V. (2008). Bourdieu and organizational analysis. Theory and Society, $37,1-44$.

Farrugia, D., \& Gerrard, J. (2016). Academic knowledge and contemporary poverty: The politics of homelessness research. Sociology, 50(2), 267-284.

Giddens, A. (1984). The Constitution of Society. Cambridge: Polity Press.

Giddens, A. (1990). The Consequences of Modernity. Cambridge: Polity Press.

Goffman, E. (1974). Asylums: Essay on the Social Situation of Mental Patients and Other Inmates. Harmondsworth: Penguin Books.

Goffman, E. (1981). Forms of Talk. Philadelphia: Philadelphia University Press.

Goffman, E. (1982). Interaction Ritual: Essays on Face-to-Face Behavior. New York: Doubleday.

Goffman, E. (1990). The Presentation of Self in Everyday Life. New York: Doubleday.

Grugulis, I. (2002). Nothing serious? Candidates' use of humour in management training. Human Relations, 55(4), 387-406.

Gubrium, J. F., \& Järvinen, M. (Eds.). (2014). Turning Troubles into Problems. Clientization in Human Service. London: Routledge.

Hammell, K. R. W. (2013). Client-centred practice in occupational therapy: Critical reflections. Scandinavian Journal of Occupational Therapy, 20(3), 174-181.

Haugaard, M. (1997). The Construction of Power: A Theoretical Analysis of Power, Knowledge and Structure. Manchester: Manchester University Press. 
Haugaard, M. (2012). Rethinking the four dimensions of power. Journal of Political Power, 5(1), $35-54$.

Haugaard, M. (2015). Concerted power over. Constellations: An International Journal of Critical and Democratic Theory, 22(1), 147-158.

Haugaard, M. (2018). What is authority? Journal of Classical Sociology, 18(2), 104-132.

Heath, C., \& Luff, P. (2012). Video analysis and organisational practice. In H. Knoblauch, B. Schnettler, J. Raab, \& H.-G. Soeffner (Eds.), Video Analysis: Methodology and Methods (pp. 35-50). Frankfurt am Main: Internationaler Verlag der Wissenschaften.

Heath, C., Hindmarsh, J., \& Luff, P. (2010). Video in Qualitative Research. Analysing Social Interaction in Everyday Life. London: Sage Publications Inc.

Heritage, J., \& Raymond, G. (2005). The terms of agreement: Indexing epistemic authority and subordination in talk-interaction. Social Psychology Quarterly, 68(1), 15-38.

Holmes, J. (2003). Small Talk at Work: Potential Problems for Workers With an Intellectual Disability. Research on Language \& Social Interaction, 36(1), 65-84.

Hoogenboom, M., \& Ossewaarde, R. (2005). From iron cage to pigeon house: The birth of reflexive authority. Organization Studies, 26(4), 601-619.

Hutson, D. J. (2013). "Your body is your business card": Bodily capital and health authority in the fitness industry. Social Science and Medicine, 90(2), 63-71.

Kangasharju, H., \& Nikko, T. (2009). Emotions in organizations: Joint laughter in workplace meetings. Journal of Business Communication, 46(1), 100-119.

Latimer, J. (2004). Commanding materials: (Re)legitimating authority in the context of multidisciplinary work. Sociology, 38(4), 757-775.

Levi, P. (1991) If This Is a Man. London: Abacus.

Luff, P. and Heath, C. (2012). Some "technical challenges" of video analysis: Social actions, 
objects, material realities and the problems of perspective. Qualitative Research, 12(3), 255279.

Manning, P. K. (2009). Reflections on “Two Concepts of Rules.” Journal of Classical Sociology, 9(4), 429-449.

May, C. (2007). The clinical encounter and the problem of context. Sociology, 41(1), 29-45.

Mik-Meyer, N., Roelsgaard Obling, A., \& Wolkowitz, C. (2018). Bodies and Intimate Relations in Organizations and Work. Gender, Work and Organization, 25(1), 1-8.

Mik-Meyer, N. (2007). Interpersonal relations or jokes of social structure? Laughter in social work. Qualitative Social Work, 6(1), 9-26.

Mik-Meyer, N. (2010). Putting the right face on a wrong body: An initial interpretation of fat identities in social work organizations. Qualitative Social Work, 9(3), 385-405.

Mik-Meyer, N. (2016) Othering, ableism and disability: A discursive analysis of coworkers'construction of colleagues with visible impairments, Human Relations, 69(6): 1341-1363. Mik-Meyer, N. (2017). The Power of Citizens and Professionals in Welfare Encounters: The Influence of Bureaucracy, Market and Psychology. Manchester: Manchester University Press.

Mik-Meyer, N. \& Silverman, D. (2019). Agency and clientship in public encounters: coconstructing 'neediness' and 'worthiness' in shelter placement meetings. British Journal of Sociology, 1-21.

Mondada, L. (2013). Displaying, contesting and negotiating epistemic authority in social interaction: Descriptions and questions in guided visits. Discourse Studies, 15(5), 597-626.

Morriss, P. (2002). Power: A Philosophical Analysis. Manchester: Manchester University Press.

Pansardi, P. (2012). Power to and power over: Two distinct concepts? Journal of Political Power 5(1), 73-89.

Parsell, C. (2011). Homeless identities: Enacted and ascribed. British Journal of Sociology, 62(3), 
$442-461$.

Parsell, C., \& Clarke, A. (2018). Agency in advanced liberal services: Grounding sociological knowledge in homeless people's accounts. British Journal of Sociology, Epub ahead of print.

Parsell, C., \& Parsell, M. (2012). Homelessness as a choice. Housing, Theory and Society, 29(4), $420-434$.

Parsons, T. (1947). The Institutionalization of Authority. In M. Weber (Ed.), The Theory of Social and Economic Organization (pp. 56-77). New York: Free Press.

Peräkylä, A. (1998). Authority and accountability: The delivery of diagnosis in primary health care. Social Psychology Quarterly, 61(4), 301-320.

Pettit, P. (2012). On the People's Terms: A Republican Theory of Democracy. Cambridge: Cambridge University Press.

Pettit, P. (2014). Just Freedom: A moral compass for a complex world. New York: Norton.

Pilnick, A., \& Zayts, O. (2016). Advice, authority and autonomy in shared decision-making in antenatal screening: The importance of context. Sociology of Health and Illness, 38(3), 343359.

Polanyi, M. (1966). The tacit dimension. Garden City, N.Y.: Doubleday.

Pouthier, V. (2017). Griping and joking as identification rituals and tools for engagement in crossboundary team meetings. Organization Studies, 38(6), 753-774.

Ravenhill, M. (2008). The culture of homelessness. Aldershot, UK: Ashgate Publishing Limited.

Rogowski, S. (2010). Social Work: The Rise and Fall of a Profession? Bristol, UK: Policy Press.

Searle, J. (2007). Social Ontology and Political Power. In Freedom and Neurobiology New York: Columbia University Press.

Shakespeare T. (1996) Disability, identity and difference. In C. Barnes and G. Mercer (Eds.), Exploring the Divide (pp. 94-113). Leeds: The Disability Press. 
Stevanovic, M., \& Peräkylä, A. (2012). Deontic authority in interaction: The right to announce, propose, and decide. Research on Language and Social Interaction, 45(3), 297-321.

Stivers, T., Heritage, J., Barnes, R. K., McCabe, R., Thompson, L., \& Toerien, M. (2018). Treatment recommendations as actions. Health Communication, 33(11), 1335-1344.

Susen, S. (2010). The transformation of citizenship in complex societies. Journal of Classical Sociology, 10(3), 259-285.

Taylor-Gooby, P. (2010). Reframing Social Citizenship. Oxford, UK: Oxford University Press.

Taylor, J. R. (2011). Organization as an (imbricated) configuring of transactions. Organization Studies, 32(9), 1273-1294.

Vinson, A. H. (2016). 'Constrained collaboration': Patient empowerment discourse as resource for countervailing power. Sociology of Health and Illness, 38(8), 1364-1378.

Ward, J., \& Winstanley, D. (2003). The absent presence: Negative space within discourse and the construction of minority sexual identity in the workplace. Human Relations, 56(10), 12551280.

Weber, M. (1978). Economy and Society (vol. 1) An outline of interpretive sociology, edited by G. Roth and C. Wittich. Berkley: University of California Press. 